https://doi.org/10.11646/zootaxa.4531.2.10

http://zoobank.org/urn:lsid:zoobank.org:pub:C6E9ADD0-9731-4FC1-BCE3-C9AA76BA027E

\title{
First record of deep-sea caridean shrimp Acanthephyra fimbriata Alcock \& Anderson, 1894 (Crustacea: Decapoda: Acanthephyridae) from southwest coast of India
}

\author{
G. KUBERAN ${ }^{1}$, REKHA DEVI CHAKRABORTY ${ }^{1,2}$, P. PURUSHOTHAMAN \& G. MAHESWARUDU \\ Crustacean Fisheries Division, Central Marine Fisheries Research Institute, Ernakulam North P.O., P.B. No. 1603, Cochin-682018, \\ Kerala, India \\ ${ }^{1}$ These authors contributed equally: G. Kuberan, Rekha Devi Chakraborty \\ ${ }^{2}$ Corresponding author. E-mail: rekhadevi7674@gmail.com
}

\begin{abstract}
The present work reports the new occurrence of deep-sea shrimp Acanthephyra fimbriata Alcock \& Anderson, 1894 from southwestern Indian waters. The samples were caught in bottom trawls conducted between the depths of 200 and $350 \mathrm{~m}$ from two fish landing centers off Kerala along Arabian Sea from the southwest coast of India during 2015. Additionally, a phylogenetic analysis was used to explore the relationships of the genus Acanthephyra based on two genes: mitochondrial cytochrome c oxidase subunit 1 (COI) and 16S DNA (16S) with the present specimen and sequences retrieved from NCBI GenBank. The results revealed intraspecies (COI: 0-3 \% \& 16S: 0-0.3\%) and interspecies divergence (COI: 17.5$20.9 \%$ \& $16 \mathrm{~S}: 5.2-9.5 \%$ ) among $A$. fimbriata.
\end{abstract}

Key words: Morphology, deep-sea, caridean shrimp, phylogenetic, Southwestern India

\section{Introduction}

The genus Acanthephyra A. Milne-Edwards, 1881 is the largest genus of the family Acanthephyridae Spence Bate, 1888, being composed by 29 species, globally distributed in tropical, temperate and some subarctic and subantarctic region (Chace 1986; De Grave \& Fransen 2011; Pohle et al. 1992; Wasmer 1986). The members of the genus are described to have pelagic life style and occur precise on mesopelagic and bathypelagic zones of ocean, inhabits mainly in deep waters from 37 to 5394 m depth (De Man 1920; Springer \& Bullis 1956; Crosnier \& Forest 1973; Chace 1986; De Grave \& Fransen 2011; Cardoso 2013; Alves-Júnior et al. 2016). The Acanthephyra fauna of India has been poorly investigated, till date only five species were recorded under this genus viz., A.armata A. Milne-Edwards, 1881, A. eximia Smith, 1884, A. curtirostris Wood-Mason \& Alcock, 1891, A. sanguinea WoodMason \& Alcock, 1892 and A. fimbriata Alcock \& Anderson, 1894 (Alcock 1901; Radhakrishnan et al. 2012; Radhika Rajasree 2011; Samuel et al. 2016). A. fimbriata in India previously recorded off Madras at $869 \mathrm{~m}$, Andaman Sea at $741 \mathrm{~m}$ and off Goa at $1023 \mathrm{~m}$ of depth from southern coast (Alcock \&Anderson 1894; Chace 1986). Although A. fimbriata was reported from Indian waters, no proper taxonomic description has been given. The present study gives detailed taxonomic information of $A$. fimbriata with molecular barcoding data and quality colored images.

\section{Materials and methods}

The specimens were collected from the two deep-sea fish landing centers, Kalamuku (off Cochin $9^{\circ} 59^{\prime} 02.91 " \mathrm{~N} /$ $76^{\circ} 14^{\prime} 33.14^{\prime \prime E}$ ), and Sakthikulangara (off Kollam $8^{\circ} 56^{\prime} 60.78^{\prime \prime N} / 76^{\circ} 32^{\prime} 34.27 " \mathrm{E}$ ) by bottom trawlers with the codend mesh size ( 20 to $26 \mathrm{~mm}$ ) in $200-350 \mathrm{~m}$ depth during $18^{\text {th }}$ November2015 and $3^{\text {rd }}$ February 2015 along the 
southwest coast of India. Samples were preserved in $95 \%$ ethanol and the voucher specimen was deposited at Central Marine Fisheries Research Institute (CMFRI), Cochin, India. The carapace length (CL) measurement refers to the dorsal distance between the posterior margin of the orbit to the posterior margin of the carapace. Total genomic DNA was extracted from the pleopods using the DNeasy ${ }^{\circledR}$ Blood \& Tissue Kit. The sequences of mitochondrial genes (COI \& 16S rDNA) were amplified using universal primers (Folmer et al. 1994; Palumbi 1996). PCR purified products were sequenced by dideoxy chain termination method (Sanger et al. 1977) using ABI Prism 3770 automated sequencer from Scigenom, India. The phylogenetic tree for COI, 16S were constructed using the statistical method maximum likelihood with 1000 bootstrap replicates (Felsenstein 1981) using MEGA7.0 software.

\section{Systematics}

\section{Order Decapoda Latreille, 1802}

\section{Infraorder Caridea Dana, 1852}

\section{Family Acanthephyridae Spence Bate, 1888}

\section{Genus Acanthephyra A. Milne-Edwards, 1881}

\section{Acanthephyra fimbriata Alcock \& Anderson, 1894}

Fig. 1 (A-E)

Acanthephyra armata.-Wood-Mason and Alcock, 1892:359, fig. 2 [not A. armata A. Milne-Edwards]. Acanthephyra armata var.-Wood-Mason, 1892, pi. 3: fig. 1.

Acanthephyra armata var. fimbriata Alcock \&Anderson, 1894: 156 [type-locality: the original specimen, described and illustrated but not named in 1892, it was reported in the Andaman Sea off Little Andaman; 11 ${ }^{\circ} 25^{\prime} 05^{\prime \prime} \mathrm{N}, 92^{\circ} 27^{\prime} 06^{\prime \prime} \mathrm{E}, 7^{2} 1$ $\mathrm{m}$; the two additional specimens were reported in 1894 from the Bay of Bengal off Madras; $12^{\circ} 50^{\prime} \mathrm{N}, 81^{\circ} 30^{\prime} \mathrm{E}, 869 \mathrm{~m}$ and off Goa; $\left.15^{\circ} 29^{\prime} \mathrm{N}, 72^{\circ} 41^{\prime} \mathrm{E}, 1023 \mathrm{~m}\right]$.

Acanthephyra fimbriata.-Chace 1986, fig. 21, 41, 51, 6j, 9c.

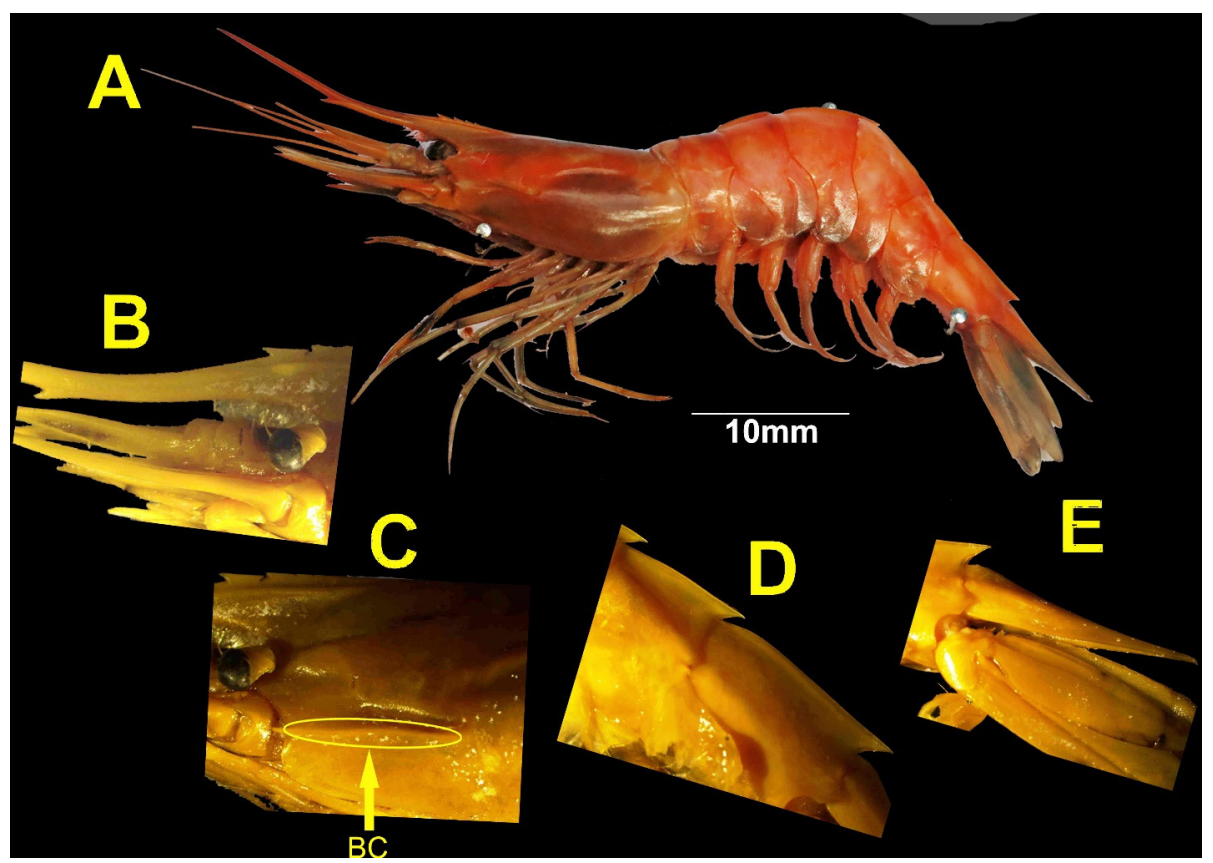

FIGURE 1. Acanthephyra fimbriata Alcock \& Anderson, 1894, Male (CL: $30 \mathrm{~mm}$ ) A. Total view. B. Lateral view of rostrum. C. Branchiostegal carina (BC) on lateral view of carapace. D. Lateral view of abdominal somites $4-6^{\text {th }}$ with the posteromesial tooth. E. Lateral view of telson. 


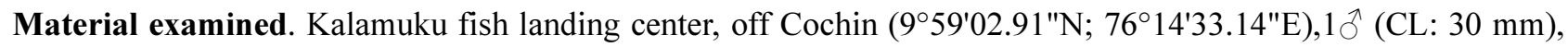
200-300 m at depth, during $18^{\text {th }}$ November 2015; Sakthikulangara (off Kollam8 $8^{\circ} 56^{\prime} 60.78^{\prime \prime} \mathrm{N} ; 76^{\circ} 32^{\prime} 34.27^{\prime \prime} \mathrm{E}$ ), $30^{\lambda}$ (CL 26-28 mm), depth at 200-350 m, during $3^{\text {rd }}$ February 2015. Voucher specimen accession number, CMFRI: ED.5.9.5.1.

Characters of specimen from off Kerala Rostrum as long as carapace, overreaching antennal scale, dorsal margin armed with 4 teeth on base, ventral margin armed with 1 tooth; carapace smooth,without carina on the entire lateral surface; antennal spine present, branchiostegal spine with strong carina, sharp carina extending posteriorly nearly to branchial region; exopod of third maxilliped and all pereopods neither foliaceous nor rigid; abdomen smooth, dorsally carinate on somites $2-6$, somites 3-6 with posteromesial tooth, third somite not deeply excavate either side of median tooth, pereopods are not slender. Telson with strong dorsal midline, with 3 dorsolateral spines (Modified from Chace 1986).

Coloration: Body is entirely reddish and orangish in the abdominal region.

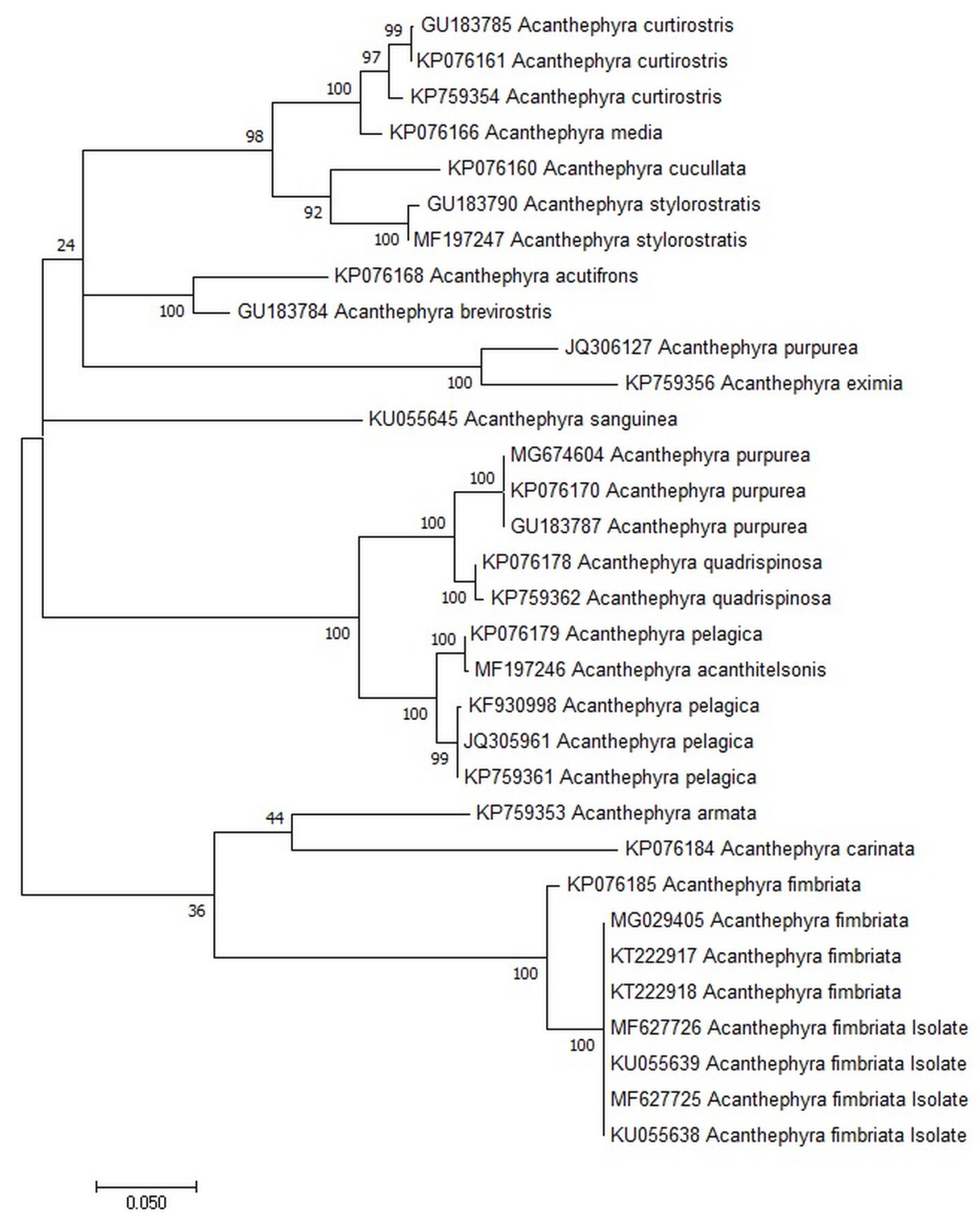

FIGURE 2. Maximum Likelihood tree for Acanthephyra COI sequences with 1000 bootstrap showing the relationship of the specimen with other related species.

Remarks: A. fimbriata is similar to A. armata, but different in the carapace with strong carina supporting branchiostegal spine to branchial region and abdomen with posterior margin of $3^{\text {rd }}$ pleura not distinctly excavate either side of the posteromedian tooth (Chace 1986). The present specimens concede well with the earlier descriptions (Alcock \& Anderson 1894; Chace 1986) without any dissimilarity. In this study, only male specimens 
were obtained from the southwest off Kerala between depths of 200 and $350 \mathrm{~m}$, but the previous records of this species was off Madras, Bay of Bengal (BOB, $869 \mathrm{~m}$ ) and Goa, Arabian Sea (AS, $1023 \mathrm{~m}$ ) at higher depths. The distributional records of this species are limited to Gulf of Aden, Andaman Sea, Bay of Bengal, Laccadive Sea, and Arabian Sea: off Goa and Philippines occurring between 412-1785 m (Chace 1986).

The gene sequence obtained from the present specimen was deposited in GenBank (Accession no's: COI, MF627725, MF627726, KU055638, KU055639; 16S, KU055642, KU055643). The sequence lengths are 540 and $407 \mathrm{bp}$ for cytochrome c oxidase I (COI) and 16S rDNA genes, respectively. The present specimen sequences was compared with the NCBI sequences of the genus Acanthephyra was obtained from the GenBank (Table. 1). The level of intraspecies genetic divergence was 3\% with COI and $0.3 \%$ in $16 \mathrm{~S}$ between the Indian and Philippines samples (COI: KP076185; 16S:KP075895) while it showed 100\% similarity within the Indian material (COI: KT222917, KT222918, MG029405; 16S:KP372713). Interspecies genetic divergence (COI: 17.5-20.9\% \& 16S: $5.2-9.5 \%$ ) between the present specimen and 14 species of Acanthephyra sequences collected from NCBI was depicted in Fig.2 \& Fig.3. COI sequence divergences of less than $3 \%$ are generally considered to be intraspecific in decapod crustaceans (Darling 2011; Vergamini et al. 2011; Yang et al. 2016).

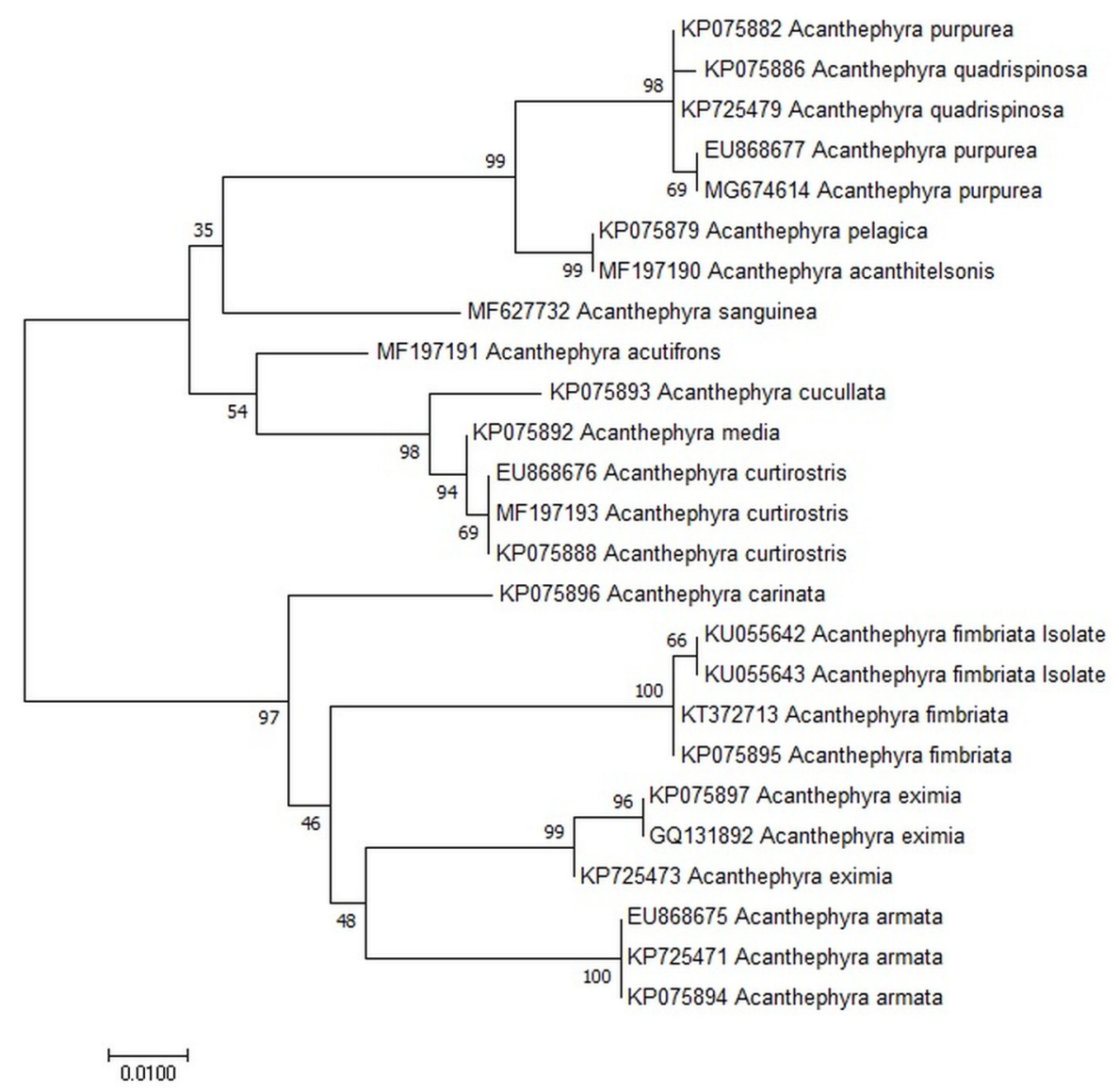

FIGURE 3. Maximum Likelihood tree for Acanthephyra 16S sequences showing with 1000 bootstrap the relationship of the specimen with other related species.

\section{Acknowledgement}

We express our thanks to the Department of Science and Technology, New Delhi, India, for financial assistance (SR/FT/LS-73/2012, SERB). The authors express their gratitude to the Director, CMFRI for the facilities provided and encouraged. We thank Dr. T.Y. Chan, Professor, and Director, National Taiwan Ocean University for confirming the taxonomic identity of the specimens. We also thank the anonymous Reviewers for improving our manuscript with their critical comments. 


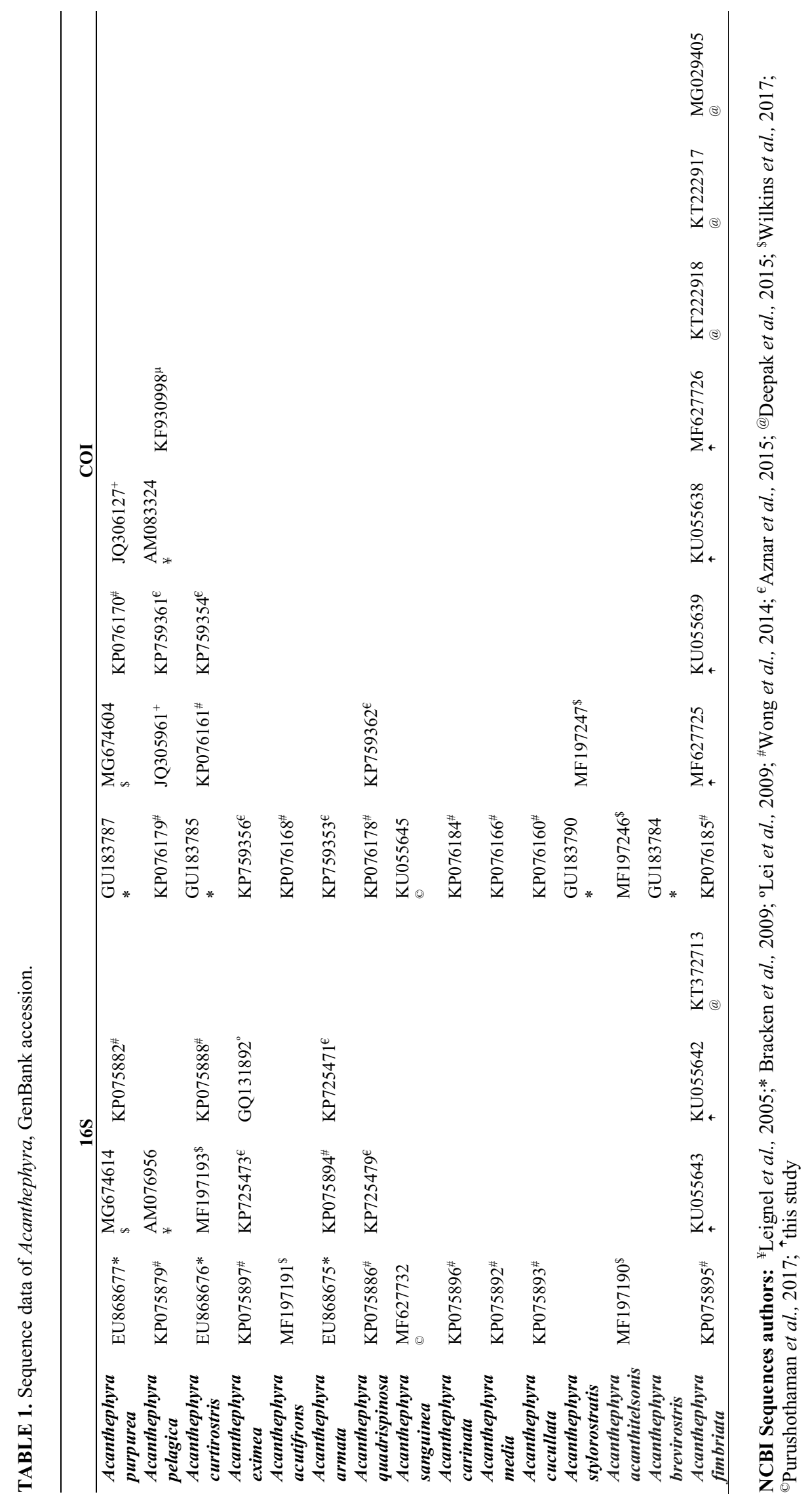




\section{References}

Alcock, A. (1901) A descriptive Catalogue of the Indian deep-sea Crustacea, Decapoda, Macrura and Anomala in the Indian Museum. Being a Revised Account of the Deep-Sea Species Collected by the Royal Indian Marine Survey Ship Investigator. Baptist Mission Press, Calcutta, India, $286 \mathrm{pp}$. https://doi.org/10.5962/bhl.title.30840

Alcock, A. \& Anderson, A. (1894) Natural history notes from H.M. Indian Marine Survey Ship "Investigator". O. F. Oldham, R. N., commading. Series II, No. 14. An account of a recent collection of deep-sea Crustacea from the Bay of Bengal and Laccadive Sea. Journal of the Asiatic Society of Bengal, 63, 141-185.

Alves-Junior, F.A., Araujo, M.S.L.C., Bertrand, A. \& Souza-Filho, J.F. (2016) First report of two deep-sea shrimps of the genus Acanthephyra A. Milne-Edwards, 1881 (Crustacea: Decapoda: Acanthephyridae) from southwestern Atlantic. Zootaxa, 4184 (1), 193-200. https://doi.org/10.11646/zootaxa.4184.1.13

Chace, F.A. (1986) The Caridean Shrimps (Crustacea: Decapoda) of the Albatross Philippine Expedition, 1907-1910, Part 4: Families Oplophoridae and Nematocarcinidae. Smithsonian contributions to zoology, 1-79. https://doi.org/10.5479/si.00810282.432

Crosnier, A. \& Forest, J. (1973) Les crevettes profondes de l'Atlantique oriental tropical. Faune Tropicale, XIX, 1-409 pp.

Dana, J.D. (1852) Conspectus of the Crustacea of the Exploring Expedition under Capt. C. Wilkes, U.S.N. Paguridea, continued, Megalopidea and Macroura. The American Journal of Science and Arts, Series, 2, 116-125.

Darling, J.A. (2011) Interspecific hybridization and mitochondrial introgression in invasive Carcinus shore crabs. Plos One, 6 (3), e17828. https://doi.org/10.1371/journal.pone.0017828

De Grave, S. \& Fransen, C.H.J.M. (2011) Carideorum Catalogus: The Recent Species of the Dendrobranchiate, Stenopodidean, Procarididean and Caridean Shrimps (Crustacea: Decapoda). Zoologische Mededelingen, 85, 195-588 pp.

De Man (1920) The Decapoda of the Siboga Expedition, IV: Families Pasiphaeidae, Stylodactylidae, Hoplophoridae, Nematocarcinidae, Thalassocaridae, Pandalidae, Psalidopodidae, Gnathophyllidae, Processidae, Glyphocrangonidae and Crangonidae. In Siboga-Expeditie, 1-318, pls. 1-25.

Felsenstein, J. (1981) Evolutionary trees from DNA sequences: A maximum likelihood approach. Journal of Molecular Evolution, 17, 368-376. https://doi.org/10.1007/BF01734359

Folmer, O., Black, M., Hoeh, W., Lutz, R. \& Vrijenhoek, R. (1994) DNA primers for amplification of mitochondrial cytochrome c oxidase subunit I from diverse metazoan invertebrates. Molecular Marine Biology and Biotechnology, 3, 294-299.

Latreille, P.A. (1802) Histoire naturelle, générale et particulière des Crustacés et des Insectes. Ouvrage faisant suite à l'histoire naturelle générale et particulière, composée par Leclerc de Buffon, et rédigée par C.S. Sonnini, membre de plusieurs Sociétés savantes. Dufart, Paris, 3, 476 pp.

Milne-Edwards, A. (1881) Description de quelques crustacés macroures provenant des grandes profondeurs de la Mer des Antilles. Annales des Sciences Naturelles, 6, 1-15.

Palumbi, S.R. (1996) Nucleic Acids II: The Polymerase Chain Reaction. In: Hillis DM, Moritz C, Mable BK (eds). Molecular Systematics, Sinauer Associates Inc, 205-247.

Pohle, G., Kenchingtoil, T.J. \& Halliday, R.G. (1992) Potentially exploitable deepwater resources off Atlantic Canada. Canadian Technical Report of Fisheries and Aquatic Sciences, 85 pp.

Radhakrishnan, E. V, Deshmukh, V.D., Maheswarudu, G., Josileen, J., Dineshbabu, A.P., Philipose, K.K., Sarada, P.T., Lakshmi Pillai, S., Saleela, K.N., Chakraborty, R., Dash, G., Sajeev, C.K., Thirumilu, P., Sridhara, B., Muniyappa, Y., Sawant, A.D., Vaidya, N.G., Johny, R.D., Verma, J.B., Baby, P.K., Unnikrishnan, C., Ramachandran, N.P., Vairamani, A., Palanichamy, A., Radhakrishnan, M. \& Raju, B. (2012) Prawn fauna (Crustacea: Decapoda) of India-An annotated checklist of the penaeoid, sergestoid, stenopodid and caridean prawns. Journal of the Marine Biological Association of India, 54, 50-72.

Radhika Rajasree, S.R. (2011) Biodiversity of deep sea prawns in the upper continental slope of Arabian sea, off Kerala (south west India): A Comparison between depths and years. Turkish Journal of Fisheries and Aquatic Sciences, 11, $291-302$.

Samuel, V.K.D., Sreeraj, C.R., Krishnan, P., Parthiban, C., Sekar, V., Chamundeeswari, K., Immanuel, T., Shesdev, P., Purvaja, R.\& \& Ramesh, R. (2016) An updated checklist of shrimps on the Indian coast. Journal of Threatened Taxa, 8977-8988. https://doi.org/10.11609/jott.2628.8.7.8977-8988

Sanger, F., Nicklen, S. \& Coulson, A.R. (1977) DNA sequencing with chain-terminating inhibitors. Proceedings of the National Academy of Sciences of the United States of America, 74, 5463-5467. https://doi.org/10.1073/pnas.74.12.5463

Smith, S.I. (1884) Report on the decapod Crustacea of the Albatross dredgings off the East coast of the United States. Reports of the United States Fisheries Commission, 345-426.

Spence Bate (1888) Report on the Crustacea Macrura collected by the Challenger during the years 1873-76. Report on the Scientific Results of the Voyage of H.M.S. "Challenger" during the years 1873-76, 1888, 1-942, Pls. 1-157.

Springer, S. \& Bullis, H.R. (1956) Collections by the Oregon in the Gulf of Mexico. U. S Fish and Wildlife Service Bureau of Commercial Fisheries. Service specially scientific Fisher, 134 pp. 
Vergamini, F.G., Pileggi, L.G. \& Mantelatto, F.L. (2011) Genetic variability of the Amazon River prawn Macrobrachium amazonicum (Decapoda, Caridea, Palaemonidae). Contributions to Zoology, 80, 67-83.

Wasmer, R. (1986) Pelagic shrimps of the Family Oplophoridae (Crustacea Decapoda) from the Pacific sector of the Southern Ocean: USNS Eltanin Cruises 10, 11, 14-16, 19-21, 24 and 25. In: L. Kornicker (ed.). Biology of the Antarctic Seas XVII. Antarctic Res, Series, 44, 29-68.

https://doi.org/10.1029/AR044p0029

Wood-Mason, J. \& Alcock, A. (1891) Natural History Notes from H.M. Indian Marine Survey Steamer "Investigator", Commander R.F. Hoskyn, R.N., commanding. The Annals and Magazine of Natural History, 8-11, 8: 16-34, 119-138, 268-286, 353-362; 9: 265-275, 3.

Wood-Mason, J. \& Alcock, A. (1892) Natural history notes from H.M. Indian marine survey steamer "Investigator", Commander R.F. Hoskyn, R.N., commanding. Series II, No. 1. On the results of deep-sea dredging during the season 1890-1891. The Annals and Magazine of Natural History, IX, 265-275, pls. XIV-XV. https://doi.org/10.1080/00222939208677319

Yang, C.H., Tsuchida, S., Fujikura, K., Fujiwara, Y., Kawato, M. \& Chan, T.Y. (2016) Connectivity of the squat lobsters Shinkaia crosnieri (Crustacea: Decapoda: Galatheidae) between cold seep and hydrothermal vent habitats. Bulletin of Marine Science, 92, 17-31.

https://doi.org/10.5343/bms.2015.1031 